Corresponding author: ahmetokay.caglayan@ istanbulbilim.edu.tr; ahmet. caglayan@yale.edu

(C) 2017 Çağlayan et al. This article is distributed under the terms of the Creative Commons Attribution License, which permits unrestricted reuse and redistribution provided that the original author and source are credited.

Ontology terms: hypertrophic cardiomyopathy

Published by Cold Spring Harbor Laboratory Press

doi: $10.1101 /$ mcs.a001859

\section{ALPK3 gene mutation in a patient with congenital cardiomyopathy and dysmorphic features}

\author{
Ahmet Okay Çağlayan, ${ }^{1,2}$ Rabia Gonul Sezer, ${ }^{3}$ Hande Kaymakçalan, ${ }^{4}$ Ege Ulgen, ${ }^{2}$ \\ Taner Yavuz, ${ }^{5}$ Jacob F. Baranoski, ${ }^{2}$ Abdulkadir Bozaykut, ${ }^{3}$ Akdes Serin Harmanci, ${ }^{2}$ \\ Yalim Yalcin, ${ }^{6}$ Mark W. Youngblood, ${ }^{2}$ Katsuhito Yasuno, ${ }^{2}$ Kaya Bilgüvar, ${ }^{7}$ \\ and Murat Gunel ${ }^{2}$

\begin{abstract}
${ }^{1}$ Department of Medical Genetics, School of Medicine, Istanbul Bilim University, Istanbul 34394, Turkey; ${ }^{2}$ Departments of Neurosurgery, Neurobiology and Genetics, Yale School of Medicine, New Haven, Connecticut 06510, USA; ${ }^{3}$ Department of Pediatrics, University of Health Sciences, Zeynep Kamil Maternity and Childrens' Diseases Training and Research Hospital, Istanbul 34668, Turkey; ${ }^{4}$ Department of Pediatrics, School of Medicine, Istanbul Bilim University, Istanbul 34394, Turkey; ${ }^{5}$ Division of Pediatric Cardiology, Department of Pediatrics, Zeynep Kamil Maternity and Childrens' Diseases Training and Research Hospital, Istanbul 34668, Turkey; ${ }^{6}$ Division of Pediatric Cardiology, Department of Pediatrics, School of Medicine, Istanbul Bilim University, Istanbul 34394, Turkey; ${ }^{7}$ Department of Genetics, Yale Center for Genome Analysis, Yale School of Medicine, New Haven, Connecticut 06510, USA
\end{abstract}

Abstract Primary cardiomyopathy is one of the most common inherited cardiac diseases and harbors significant phenotypic and genetic heterogeneity. Because of this, genetic testing has become standard in treatment of this disease group. Indeed, in recent years, next-generation DNA sequencing has found broad applications in medicine, both as a routine diagnostic tool for genetic disorders and as a high-throughput discovery tool for identifying novel disease-causing genes. We describe a male infant with primary dilated cardiomyopathy who was diagnosed using intrauterine echocardiography and found to progress to hypertrophic cardiomyopathy after birth. This proband was born to a nonconsanguineous family with a past history of a male fetus that died because of cardiac abnormalities at 30 wk of gestation. Using whole-exome sequencing, a novel homozygous frameshift mutation (c.2018delC; p.Gln675SerfsX30) in ALPK3 was identified and confirmed with Sanger sequencing. Heterozygous family members were normal with echocardiographic examination. To date, only two studies have reported homozygous pathogenic variants of ALPK3, with a total of seven affected individuals with cardiomyopathy from four unrelated consanguineous families. We include a discussion of the patient's phenotypic features and a review of relevant literature findings.

[Supplemental material is available for this article.]

\section{INTRODUCTION}

Cardiomyopathy (CMP) is classified into primary and secondary forms based on the involvement of other organ systems (Maron et al. 2006). There are several different clinical subtypes of primary cardiomyopathy, with hypertrophic cardiomyopathy (HCM) and dilated cardiomyopathy (DCM) being the two most prevalent (Towbin and Bowles 2002; Ahmad et al. 2005). The annual incidence of pediatric cardiomyopathy is around 1.13 cases in 100,000 children younger than $18 \mathrm{yr}$ of age and 8.34 cases per 100,000 infants (Wilkinson et al. 2011; 
Mestroni et al. 2016). HCM is characterized by left ventricular hypertrophy (LVH) and results in a range of cardiac output and hemodynamic abnormalities. HCM affects approximately 1 in 500 adults globally and is considered to be the result of mutations affecting the sarcomere proteins that comprise the heart's contractile apparatus (Maron et al. 1995; Elliott et al. 2008; Harvey and Leinwand 2011; Semsarian et al. 2015). Histological features of HCM include interstitial fibrosis and myocyte enlargement and disarray. DCM, on the other hand, is characterized by increased left ventricular end diastolic diameter (Elliott et al. 2008). Idiopathic DCM carries a prevalence likely exceeding 1 in 250 (Hershberger et al. 2013) and is histologically characterized by cardiomyocyte hypertrophy, loss of myofibrils, and interstitial fibrosis (Cahill et al. 2013). Both HCM and DCM are responsible for heart failure, arrhythmias, and sudden cardiac death at any age worldwide (Maron and Maron 2013); and DCM is the most common indication for cardiac transplantation (Stehlik et al. 2012). Furthermore, both $\mathrm{HCM}$ and DCM display locus and allelic heterogeneity, and most mutations lead to an autosomal dominant pattern of inheritance with variable expression and incomplete penetrance (Hershberger and Siegfried 2011; Yingchoncharoen and Tang 2014). However, other inheritance patterns have been reported, including X-linked (Towbin et al. 1993), mitochondrial (Zaragoza et al. 2011), and autosomal recessive transmission in DCM and X-linked and recessive in HCM (Burke et al. 2016).

Next-generation sequencing (NGS) technologies are being utilized to identify novel disease-causing genes to further elucidate the unsolved causes of cardiomyopathy (Ware et al. 2012). Recently, homozygous null variants in ALPK3 were reported as a novel cause of severe pediatric cardiomyopathy in five patients from three unrelated consanguineous families by Almomani et al. (2016). A report by Phelan et al. (2016) described an additional two affected individuals with CMP and ALPK3 mutation and demonstrated abnormal calcium transport in ALPK3-mutant cardiomyocytes. Furthermore, two individuals with heterozygous null variants in ALPK3 from Almomani's report were diagnosed with an atypical form of $\mathrm{HCM}$ at a young adult age. Here we report a null variant in the autosomal recessively inherited cardiomyopathy gene ALPK3, which was identified in a patient who initially presented with DCM that later progressed to $\mathrm{HCM}$.

\section{RESULTS}

\section{Clinical Presentation and Family History}

The index case is a $2 \frac{1}{2} 2$-year-old male who was born preterm at $32 \mathrm{wk}$ of gestation as a product of a reported nonconsanguineous union (however, parents were found to be from the same village with a small population during clinical evaluation of the patient). Family history was notable for a previous pregnancy in which the male fetus died because of cardiac abnormalities at $30 \mathrm{wk}$ of gestation (Fig. 1A). However, no patient material from this previous fetus was available for clinical and/or laboratory examination. Fetal echocardiography at $21 \mathrm{wk}$ of gestation of the index case demonstrated cardiomegaly (heart/thorax ratio of 0.8 ), decreased cardiac contractility, and thickened trabecular layer and moderator band. His end-diastolic interventricular septum diameter was measured at $3.9 \mathrm{~mm}$, left ventricular end-diastolic diameter at $10.6 \mathrm{~mm}$, and ejection fraction at $34 \%$; a mild mitral valve insufficiency was also noted. A diagnosis of DCM was made. When he was 4 mo old, his weight was $5010 \mathrm{~g}$ (10th percentile), height was $59 \mathrm{~cm}$ (25-50th percentile), and head circumference was $39 \mathrm{~cm}$ (10th percentile). His examination revealed dysmorphic face including low-set ears and high arched palate. At the same age, two-dimensional echocardiography demonstrated diffuse left ventricular (LV) hypertrophy, with normal ejection fraction (LV end-diastolic diameter of $18 \mathrm{~mm}$, end-systolic interventricular septum diameter of $7 \mathrm{~mm}$, end-diastolic interventricular septum diameter of $5 \mathrm{~mm}$, end-systolic LV posterior wall diameter of $9 \mathrm{~mm}$, 
A

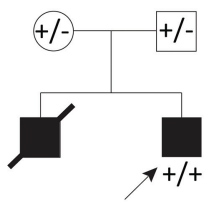

$\mathbf{A}$

B
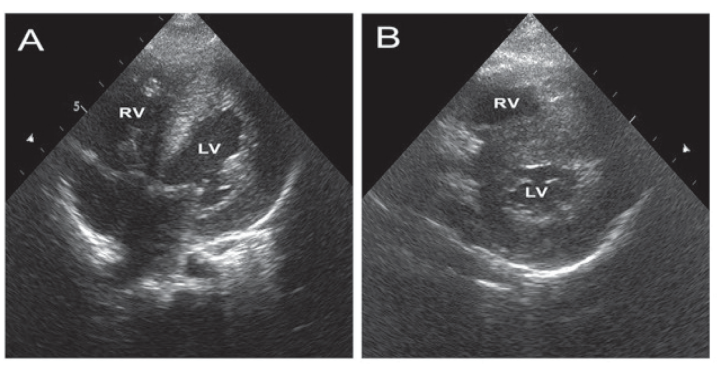

C

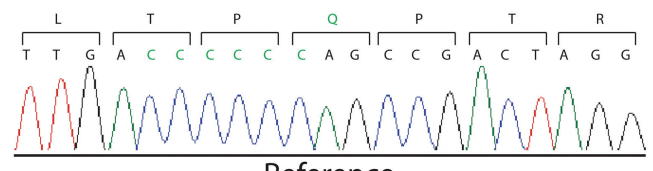

Reference

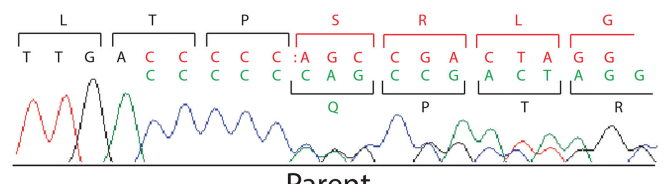

Parent

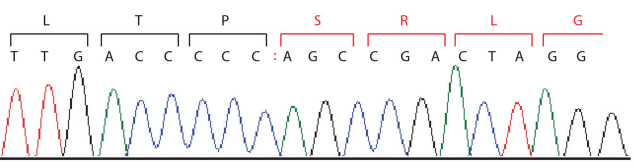

Homozygous Proband

D

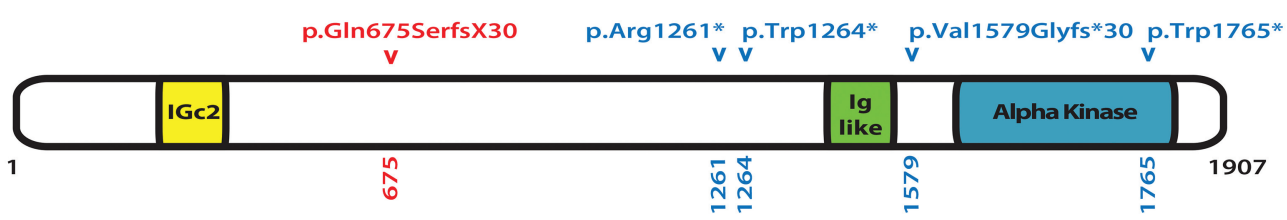

Figure 1. (A) Pedigree of the family demonstrating the affected siblings and, when available, their ALPK3 genotypes. (B) Transthoracic echocardiogram of apical four-chamber view (left) showing symmetrically thickened left ventricular wall and ventricular septum. Parasternal short-axis view (right) showed diffuse concentric left ventricular hypertrophy. RV, right ventricle; LV, left ventricle. (C) Sanger sequencing results. Chromatographs obtained via Sanger sequencing analysis of the index patient and his parents. Sanger sequencing of wild-type control DNA was also performed. Note that the mutation identified via whole-exome sequencing was confirmed as being homozygous versus heterozygous, in the index patient versus his parents, respectively. The bases outlined in red in the wild-type sequence indicate the mutated base pairs. (D) A schematic representation of ALPK3, showing the functional and conserved domains of ALPK3. The red arrowhead indicates the location of the identified variant in this study. Blue arrowheads indicate previously reported variants.

and end-diastolic LV posterior wall diameter of $6 \mathrm{~mm}$ ). An LV outflow tract obstruction was not present on Doppler echocardiographic examination (Fig. 1B). These clinical findings were sufficient for a diagnosis of HCM. The parents were subsequently screened for cardiomyopathy with normal echocardiogram results.

\section{Genomic Analyses \\ Whole-Exome Sequencing}

We performed whole-exome capture and sequencing of germline DNA obtained from the index case (Supplemental Table 1). Both parents were Sanger sequenced for the identified variants to complete segregation analysis. Whole-exome sequencing data were analyzed using an in-house bioinformatics pipeline as described in detail previously (Clark et al. 2013). We identified all exomic variants, classifying them as either single-nucleotide variants (synonymous, loss-of-function, or missense variants) or insertion/deletions, and we calculated both the heterozygous and homozygous population allele frequencies of each of the variants. We used a population cutoff of $0.01 \%$ to filter for candidate causative genomic events, 
after annotating each variant with its frequency in a Yale in-house exome sequence database $(n>5000)$ and the Exome Aggregation Consortium (ExAC), ESP6500 and the 1000 Genome databases. Using this approach, eight homozygous novel variants were identified in the homozygous-by-descent (HBD) genomic segments of the index case (Table 1). All but one (TNK2) of the variants that were identified in the affected individual segregated with the phenotype within the family. Notable variants included frameshift mutations in ALPK3 and KANSL1L and a missense variant in the previously established X-linked deafness gene POU3F. The mutation in ALPK3 was a homozygous 1-bp deletion (ENST00000258888.5: c.2018delC), resulting in a predicted premature termination (ENSP00000258888.5:p. Gln675SerfsX30) (Fig. 1C). This mutation segregated in the family in an autosomal recessive mode of inheritance with the patient being homozygous and both unaffected parents being heterozygous. The ALPK3 variant observed in our study has not previously been reported in a homozygous state in the Database for Short Genetic Variartions (dbSNP) (Sherry et al. 2001), Exome Variant Server, National Heart, Lung, and Blood Institute (NHLBI) GO Exome Sequencing Project (ESP), Seattle, WA, ExAC (Lek et al. 2016), or 1000 Genomes (1000 Genomes Project Consortium et al. 2015) databases nor has it been observed within a cohort of 3000 subjects with nonneurological diseases who were whole-exome-sequenced at Yale School of Medicine. However, it has been reported in a heterozygous state twice with $1.755 \times 10^{-05}$ allele frequency in the ExAc database and five times with $2.096 \times 10^{-5}$ allele frequency in the gnomAD browser (Lek et al. 2016). In addition, copy-number variation analysis (based on exome sequencing of the index case) demonstrated no disease-causing largescale amplifications, deletions, or loss of heterozygosity within the coding regions of the entire genome. Applying American College of Medical Genetics and Genomics and the Association for Molecular Pathology criteria PVS1, PM3, and PM2, we classified the variant as pathogenic (Richards et al. 2015). These findings provide strong genetic evidence that the identified ALPK3 variant is the disease-causing variant in this family.

\section{DISCUSSION}

Human a-protein kinase 3 (ALPK3) consists of 14 exons and encodes a 1907-aa protein that contains one a-type protein kinase domain and two Ig-like (immunoglobulin-like) domains (Fig. 1D). Although the specific role of ALPK3 remains unclear, it may act as a regulator of cardiac transcription factors such as HEY2 (Hosoda et al. 2001; Almomani et al. 2016). Notably, Van Sligtenhorst et al. (2012) observed cardiomyopathy in mice deficient for Alpk3 that were otherwise phenotypically normal. Alpk $3^{-1-}$ mice exhibited nonprogressive cardiomyopathy that had features of both hypertrophic and dilated forms, which is consistent with observations in the patient of our study.

Although hypertrophic and dilated cardiomyopathies were classically described as distinct entities, it has been suggested that these two types of cardiomyopathy may represent different stages within a pathological spectrum (Freeman et al. 2001). Our patient presented with congenital cardiomyopathy that was diagnosed during fetal life similar with previous reports. However, following birth of the patient, cardiac morphology, which was found to be dilated during the fetal life, progressed to HCM. Although it has been previously shown that cases with HCM may progress to DCM (Spirito et al. 1987; Hecht et al. 1993), we did not find any report in the literature showing progression of DCM to HCM. Almomani et al. (2016) also reported that the patients who were lost during the intrauterine life or immediately following the delivery (three out of five patients) exhibited features of DCM or a combination of DCM and HCM. Interestingly, two individuals that were heterozygous carriers for the reported ALPK3 variant (c.5295G.A; p.Trp1765*) from the Almomani report were diagnosed with an atypical form of HCM during early 
Table 1. Variants detected via whole-exome sequencing

\begin{tabular}{|c|c|c|c|c|c|c|c|c|}
\hline $\begin{array}{l}\text { Gene } \\
\text { symbol }\end{array}$ & $\begin{array}{l}\text { Chromosome: } \\
\text { position start }\end{array}$ & $\begin{array}{l}\text { Reference } \\
\text { DNA }\end{array}$ & $\begin{array}{l}\text { Alternative } \\
\text { DNA }\end{array}$ & HGVSc & HGVSp & $\begin{array}{l}\text { Variant } \\
\text { type }\end{array}$ & $\begin{array}{l}\text { Existing } \\
\text { variation }\end{array}$ & $\begin{array}{c}\text { Genotype } \\
\text { (heterozygous/ } \\
\text { homozygous) }\end{array}$ \\
\hline ALPK3 & $15: 85,383,921$ & $A C$ & A & c.2018delC & p.Gln675SerfsX30 & Frameshift & & Homozygous \\
\hline ARHGAP6 & $X: 11,157,357$ & C & $\mathrm{T}$ & c. $2551 \mathrm{G}>\mathrm{A}$ & p.Glu851Lys & Missense & & Homozygous \\
\hline DOCK11 & $X: 117,702,043$ & A & G & c. $953 \mathrm{~A}>\mathrm{G}$ & p.Tyr318Cys & Missense & & Homozygous \\
\hline $\mathrm{HEPH}$ & $X: 65,417,725$ & G & C & c. $1573 G>C$ & p.Asp $525 \mathrm{His}$ & Missense & rs3747359 & Homozygous \\
\hline KANSL1L & $2: 210,887,679$ & $A$ & AT & c.2831dupA & p.Asn944LysfsX2 & Frameshift & & Homozygous \\
\hline POU3F4 & $X: 82,763,774$ & G & $\mathrm{C}$ & c. $442 \mathrm{G}>\mathrm{C}$ & p.Gly148Arg & Missense & $\begin{array}{l}\text { Two hemizygotes } \\
\text { with } 0.00006970 \\
\text { allele frequency } \\
\text { and four } \\
\text { heterozygotic } \\
\text { states in ExAC } \\
\text { database }\end{array}$ & Homozygous \\
\hline RRAGB & $X: 55,784,736$ & A & G & c. $1001 \mathrm{~A}>\mathrm{G}$ & p.Glu334Gly & Missense & & Homozygous \\
\hline TNK2 & $3: 195,594,921$ & $\mathrm{C}$ & $\mathrm{T}$ & c. $2299 \mathrm{G}>\mathrm{A}$ & p.Asp767Asn & Missense & rs373598238 & Homozygous \\
\hline
\end{tabular}

HGVSc, Human Genome Variation Society coding sequence name; HGVSp, Human Genome Variation Society protein sequence name; ExAC, Exome Aggregation Consortium.

adulthood. In our study, cardiac examination of heterozygous carriers revealed no evidence of cardiomyopathy, however as suggested by Almomani et al., ALPK3 pathogenic variant carriers might have an increased risk of developing cardiomyopathy. Clarification of the risk status of heterozygous carriers with ALPK3 mutations will require further genotype/ phenotype correlations with larger cohorts. Of note, Phelan et al., in their report, extended the ALPK3 phenotype to include congenital pterygia which is not seen in the presented case (Table 2).

Previous studies have investigated the downstream molecular mechanisms of cardiomyopathy-associated gene mutations. Induced pluripotent stem cell-derived cardiomyocytes (iPSC-CMs) were used to successfully recapitulate the disease phenotype from genes associated with DCM (Sylvius and Tesson 2006; Siu et al. 2012; Sun et al. 2012; Tse et al. 2013) and HCM (Lan et al. 2013). Phelan et al. showed that ALPK3 knockout human embryonic stem cells (hESCs) recapitulate the cellular phenotype of patient-derived iPSCs. Heterozygous correction of ALPK3 was sufficient to fully restore a wild-type phenotype in the patient-derived cells. Electron microscopy of ALPK3-mutant and control cardiomyocytes derived from both iPSC and hESC lines demonstrated sarcomeric disorganization and abnormal intercalated disc morphology in mutant cardiomyocytes.

\section{Conclusions}

We provide further evidence for involvement of ALPK3 in cardiomyopathy, as well as identify a unique progression of DCM to HCM. This study underscores the essential role of genetic testing in congenital cardiomyopathy, which should guide appropriate counseling and screening of other family members. Because inherited cardiomyopathies are frequently early-onset and are a major contributor to morbidity and mortality in the young, identification of a pathogenic variant can lead to individualized approaches including symptom management and lifestyle recommendations, family screening, and intervention at a preventive stage. 
Table 2. Summary of clinical and molecular findings in ALPK3 deficiency

\begin{tabular}{|c|c|c|c|c|}
\hline Previous paper & Almomani et al. (2016) & Phelan et al. (2016) & \multicolumn{2}{|c|}{ Present report (2017) } \\
\hline Number of families & 3 & 1 & 1 & \\
\hline Number of cases & 5 & 2 & 2 & \\
\hline Ethnic origin & Dutch, Moroccan, Turkish & Pakistani & Turkish & \\
\hline Parental consanguinity & Consanguineous & Consanguineous (first cousins) & Same village & \\
\hline Sex & Female (3), male (2) & Female, male & Male & Male \\
\hline Age of diagnosis & $\begin{array}{l}\text { At } 20 \text { wk of gestation to } 4 \text { years } \\
\text { of age }\end{array}$ & Early infancy & Intrauterine & 21 wk of gestation \\
\hline Predominant CMP type & $\begin{array}{l}\text { DCM or mixed DCM to } \mathrm{HCM} \\
\text { phenotypes }\end{array}$ & $\begin{array}{l}\text { Initially left ventricular dilation } \\
\text { and then syndromic HCM }\end{array}$ & NA & $\begin{array}{l}\text { Initially DCM and then } \\
\text { HCM phenotype }\end{array}$ \\
\hline Survival & $\begin{array}{l}\text { Intrauterine fetal death at } 35 \mathrm{wk} \text { to } \\
\text { died at } 5 \text { days }(3 / 5) \text {, alive } \\
\text { (ages }>7 \text { years, } 11 \text { years) }(2 / 5)\end{array}$ & Alive (age >18, ?) (2/2) & $\begin{array}{r}\text { Died at } 30 \text { wk } \\
\text { of gestation }\end{array}$ & Alive (age >3 years) \\
\hline Other findings & Massive skin edema & $\begin{array}{l}\text { Multiple pterygia with skeletal } \\
\text { muscle underdevelopment }\end{array}$ & None & Dysmorphic face \\
\hline $\begin{array}{l}\text { Carrier phenotype/ } \\
\text { genotype/CMP } \\
\text { type/mean age }\end{array}$ & $\begin{array}{l}\text { Affected }(2 / 10) / c .5294 \mathrm{G}>\mathrm{A}, \\
\text { p.Trp1765*/HCM/44 years old }\end{array}$ & Normal (4/4) & Normal (2/2) & \\
\hline Genotype & $\begin{array}{l}\text { c. } 4736-1 \mathrm{G}>\text { A, p.Val1579Glyfs*30; } \\
\text { c.3781C>T, p.Arg1261*; } \\
\text { c.5294G >A, p.Trp1765* }\end{array}$ & c. 3792 G.A, p.Trp1264* & Not tested & $\begin{array}{l}\text { c. } 2018 \text { delC, } \\
\text { p.Gln675Serfs*30 }\end{array}$ \\
\hline
\end{tabular}

NA, not applicable; DCM, dilated cardiomyopathy; HCM, hypertrophic cardiomyopathy.

\section{METHODS}

\section{DNA Extraction}

Blood samples were collected from the infant and his parents. DNA was extracted using the commercially available Gentra Puregene Blood Kit from QIAGEN.

\section{Whole-Exome Capture, Sequencing, and Data Analysis}

Exome capture for all samples was performed using the NimbleGen 2.1 $\mathrm{M}$ human exome array (Roche Nimblegen Inc.) according to the manufacturer's protocol with modifications, described previously (Choi et al. 2009; Bilgüvar et al. 2010). Exome library sequencing was performed using an Illumina HiSeq2000 with barcoding technology, paired-end analysis, and six samples per lane. Image analysis and subsequent base-calling was performed using the Illumina pipeline (version 1.8). Analysis of the sequencing data was performed according to previously described in-house bioinformatics pipelines (Clark et al. 2013). Briefly, sequence reads that met Illumina quality standards were analyzed and aligned to the human genome reference sequence (version GRCh37, as utilized in phase 1 of the 1000 Genomes Project) using a hybrid of Stampy (Lunter and Goodson 2011) and BurrowsWheeler alignment (BWA) (Li and Durbin 2009). Variant calling of single-nucleotide variants (SNVs) and small indels was accomplished using the Unified Genotyper algorithm from the Genome Analysis Toolkit (GATK) (DePristo et al. 2011). We annotated variant alleles using the Ensembl database (version 66) and Variant Effect Predictor (v2.4) tool (McLaren et al. 2010). To detect HBD segments, we used an algorithm implemented in BEAGLE v3.3.2. (Browning and Browning 2010). We adopted the default settings and ran the algorithm 10 times with different random seeds as suggested by the authors. We filtered HBD segments with final length of $<0.25 \mathrm{cM}$. 


\section{Sanger Sequencing}

Coding regions and exon-intron boundaries of ALPK3 were evaluated by Sanger sequencing using standard protocols (Supplemental Table 2). Amplicons were cycle-sequenced on $A B \mid 9800$ Fast Thermo cyclers, and post-cycle sequencing cleanup was carried out with the CleanSEQ System (Beckman Coulter Genomics). The amplicons were analyzed with a $3730 \times$ L DNA Analyzer (Applied Biosystems Inc).

\section{Copy-Number Variation Analysis}

The depth of coverage log ratio between patient sample and control samples were calculated using GATK-Depth of Coverage tool. Segments with copy-number variations (CNVs) were identified from the log ratio of depth of coverage using the ExomeCNV R package (Sathirapongsasuti et al. 2011). False-positive CNV events were identified and corrected for by calculating minor allele frequencies in each CNV segment.

\section{ADDITIONAL INFORMATION}

\section{Data Deposition and Access}

Whole-exome sequencing data are not publicly available because consent could not be obtained. The variant associated with the phenotype has been submitted to ClinVar to be deposited and can be found under accession number SCV000540917 (https://www.ncbi. nlm.nih.gov/clinvar/).

\section{Ethics Statement}

The study protocol was approved by the Yale School of Medicine Human Investigation Committee (HIC) (protocol number 0908005592). Institutional review board approvals for genetic studies, along with written consent from all study subjects, were obtained by the referring physicians at the participating institutions. Informed consent to publish clinical data of the patient was signed by the parents.

\section{Acknowledgments}

We thank the reported family for participating in this study.

\section{Author Contributions}

A.O.C. had full access to all data in this study and takes responsibility for the integrity of the data and the accuracy of the data analysis. M.G., A.O.C., and K.B. contributed to the study concept and design and the overall acquisition, analysis, or interpretation of data. R.G.S., T.Y., A.B., H.K., and Y.Y. contributed to patient recruitment. A.O.C. contributed to WES

Competing Interest Statement

The authors have declared no competing interest.

\section{Referees}

Dean G. Phelan

Alireza Haghighi

Anonymous

Received January 24, 2017; accepted in revised form May 24, 2017. data analysis, and interpretation. K.Y. contributed to the in-house WES pipeline. A.S.H. contributed to the CNV analysis. A.O.C. and E.U. contributed to the Sanger sequencing. A.O.C., K.B., J.F.B., and M.W.Y. contributed to the drafting of the manuscript. All authors contributed to the critical revision of the manuscript for important intellectual content. M.G. obtained funding and contributed to study supervision.

\section{Funding}

This work was supported by the Yale Program on Neurogenetics and the Yale Center for Mendelian Disorders (U54HG006504), the National Institutes of Health (NIH) Medical Scientist Training Program Grant T32GM007205, and the Gregory M. Kiez and Mehmet Kutman Foundation (M.G.). 


\section{REFERENCES}

Ahmad F, Seidman JG, Seidman CE. 2005. The genetic basis for cardiac remodeling. Annu Rev Genomics Hum Genet 6: 185-216.

Almomani R, Verhagen JM, Herkert JC, Brosens E, van Spaendonck-Zwarts KY, Asimaki A, van der Zwaag PA, Frohn-Mulder IM, Bertoli-Avella AM, Boven LG, et al. 2016. Biallelic truncating mutations in ALPK3 cause severe pediatric cardiomyopathy. J Am Coll Cardiol 67: 515-525.

Bilgüvar K, Oztürk AK, Louvi A, Kwan KY, Choi M, Tatli B, Yalnizoğlu D, Tüysüz B, Çağlayan AO, Gökben S, et al. 2010. Whole-exome sequencing identifies recessive WDR62 mutations in severe brain malformations. Nature 467: 207-210.

Browning SR, Browning BL. 2010. High-resolution detection of identity by descent in unrelated individuals. Am J Hum Genet 86: 526-539.

Burke MA, Cook SA, Seidman JG, Seidman CE. 2016. Clinical and mechanistic insights into the genetics of cardiomyopathy. J Am Coll Cardiol 68: 2871-2886.

Cahill TJ, Ashrafian H, Watkins H. 2013. Genetic cardiomyopathies causing heart failure. Circ Res 113: 660-675.

Choi M, Scholl UI, Ji W, Liu T, Tikhonova IR, Zumbo P, Nayir A, Bakkaloğlu A, Ozen S, Sanjad S, et al. 2009. Genetic diagnosis by whole exome capture and massively parallel DNA sequencing. Proc Natl Acad Sci 106: 19096-19101.

Clark VE, Erson-Omay EZ, Serin A, Yin J, Cotney J, Ozduman K, Avşar T, Li J, Murray PB, Henegariu O, et al. 2013. Genomic analysis of non-NF2 meningiomas reveals mutations in TRAF7, KLF4, AKT1, and SMO. Science 339: 1077-1080.

DePristo MA, Banks E, Poplin R, Garimella KV, Maguire JR, Hartl C, Philippakis AA, del Angel G, Rivas MA, Hanna $M$, et al. 2011. A framework for variation discovery and genotyping using next-generation DNA sequencing data. Nat Genet 43: 491-498.

Elliott P, Andersson B, Arbustini E, Bilinska Z, Cecchi F, Charron P, Dubourg O, Kühl U, Maisch B, McKenna WJ, et al. 2008. Classification of the cardiomyopathies: a position statement from the European Society of Cardiology Working Group on Myocardial and Pericardial Diseases. Eur Heart J 29: 270-276.

Freeman K, Colon-Rivera C, Olsson MC, Moore RL, Weinberger HD, Grupp IL, Vikstrom KL, laccarino G, Koch WJ, Leinwand LA. 2001. Progression from hypertrophic to dilated cardiomyopathy in mice that express a mutant myosin transgene. Am J Physiol Heart Circ Physiol 280: H151-H159.

1000 Genomes Project Consortium, Auton A, Brooks LD, Durbin RM, Garrison EP, Kang HM, Korbel JO, Marchini JL, McCarthy S, McVean GA, et al. 2015. A global reference for human genetic variation. Nature 526: 68-74.

Harvey PA, Leinwand LA. 2011. The cell biology of disease: cellular mechanisms of cardiomyopathy. J Cell Biol 194: 355-365.

Hecht GM, Klues HG, Roberts WC, Maron BJ. 1993. Coexistence of sudden cardiac death and end-stage heart failure in familial hypertrophic cardiomyopathy. J Am Coll Cardiol 22: 489-497.

Hershberger RE, Siegfried JD. 2011. Update 2011: clinical and genetic issues in familial dilated cardiomyopathy. J Am Coll Cardiol 57: 1641-1649.

Hershberger RE, Hedges DJ, Morales A. 2013. Dilated cardiomyopathy: the complexity of a diverse genetic architecture. Nat Rev Cardiol 10: 531-547.

Hosoda T, Monzen K, Hiroi Y, Oka T, Takimoto E, Yazaki Y, Nagai R, Komuro I. 2001. A novel myocyte-specific gene Midori promotes the differentiation of P19CL6 cells into cardiomyocytes. J Biol Chem 276: 35978-35989.

Lan F, Lee AS, Liang P, Sanchez-Freire V, Nguyen PK, Wang L, Han L, Yen M, Wang YM, Sun N, et al. 2013. Abnormal calcium handling properties underlie familial hypertrophic cardiomyopathy pathology in patient-specific induced pluripotent stem cells. Cell Stem Cell 12: 101-113.

Lek M, Karczewski KJ, Minikel EV, Samocha KE, Banks E, Fennell T, O’Donnell-Luria AH, Ware JS, Hill AJ, Cummings BB, et al. 2016. Analysis of protein-coding genetic variation in 60,706 humans. Nature 536: 285-291.

Li H, Durbin R. 2009. Fast and accurate short read alignment with Burrows-Wheeler transform. Bioinformatics 25: $1754-1760$.

Lunter G, Goodson M. 2011. Stampy: a statistical algorithm for sensitive and fast mapping of Illumina sequence reads. Genome Res 21: 936-939.

Maron BJ, Maron MS. 2013. Hypertrophic cardiomyopathy. Lancet 381: 242-255.

Maron BJ, Gardin JM, Flack JM, Gidding SS, Kurosaki TT, Bild DE. 1995. Prevalence of hypertrophic cardiomyopathy in a general population of young adults. Echocardiographic analysis of 4111 subjects in the CARDIA Study. Coronary Artery Risk Development in (Young) Adults. Circulation 92: 785-789.

Maron BJ, Towbin JA, Thiene G, Antzelevitch C, Corrado D, Arnett D, Moss AJ, Seidman CE, Young JB; American Heart Association, et al. 2006. Contemporary definitions and classification of the cardiomyop- 
athies: an American Heart Association Scientific Statement from the Council on Clinical Cardiology, Heart Failure and Transplantation Committee; Quality of Care and Outcomes Research and Functional Genomics and Translational Biology Interdisciplinary Working Groups; and Council on Epidemiology and Prevention. Circulation 113: 1807-1816.

McLaren W, Pritchard B, Rios D, Chen Y, Flicek P, Cunningham F. 2010. Deriving the consequences of genomic variants with the Ensembl API and SNP Effect Predictor. Bioinformatics 26: 2069-2070.

Mestroni L, Sweet ME, Taylor MR. 2016. Pediatric cardiomyopathy: new Insight Into potential disease mechanisms. J Am Coll Cardiol 67: 526-528.

Phelan DG, Anderson DJ, Howden SE, Wong RC, Hickey PF, Pope K, Wilson GR, Pébay A, Davis AM, Petrou S, et al. 2016. ALPK3-deficient cardiomyocytes generated from patient-derived induced pluripotent stem cells and mutant human embryonic stem cells display abnormal calcium handling and establish that ALPK3 deficiency underlies familial cardiomyopathy. Eur Heart J 37: 2586-2590.

Richards S, Aziz N, Bale S, Bick D, Das S, Gastier-Foster J, Grody WW, Hegde M, Lyon E, Spector E, et al. 2015. Standards and guidelines for the interpretation of sequence variants: a joint consensus recommendation of the American College of Medical Genetics and Genomics and the Association for Molecular Pathology. Genet Med 17: 405-424.

Sathirapongsasuti JF, Lee H, Horst BA, Brunner G, Cochran AJ, Binder S, Quackenbush J, Nelson SF. 2011. Exome sequencing-based copy-number variation and loss of heterozygosity detection: ExomeCNV. Bioinformatics 27: 2648-2654.

Semsarian C, Ingles J, Maron MS, Maron BJ. 2015. New perspectives on the prevalence of hypertrophic cardiomyopathy. J Am Coll Cardiol 65: 1249-1254.

Sherry ST, Ward MH, Kholodov M, Baker J, Phan L, Smigielski EM, Sirotkin K. 2001. dbSNP: the NCBI database of genetic variation. Nucleic Acids Res 29: 308-311.

Siu CW, Lee YK, Ho JCY, Lai WH, Chan YC, Ng KM, Wong LY, Au KW, Lau YM, Zhang JQ, et al. 2012. Modeling of lamin $A / C$ mutation premature cardiac aging using patient-specific induced pluripotent stem cells. Aging (Albany NY) 4: 803-822.

Spirito P, Maron BJ, Bonow RO, Epstein SE. 1987. Occurrence and significance of progressive left ventricular wall thinning and relative cavity dilatation in hypertrophic cardiomyopathy. Am J Cardiol 60: 123-129.

Stehlik J, Edwards LB, Kucheryavaya AY, Benden C, Christie JD, Dipchand AI, Dobbels F, Kirk R, Rahmel AO, Hertz MI, et al. 2012. The Registry of the International Society for Heart and Lung Transplantation: 29th official adult heart transplant report-2012. J Heart Lung Transplant 31: 1052-1064.

Sun N, Yazawa M, Liu JW, Han L, Sanchez-Freire V, Abilez OJ, Navarrete EG, Hu SJ, Wang L, Lee A, et al. 2012. Patient-specific induced pluripotent stem cells as a model for familial dilated cardiomyopathy. Sci Trans Med 4: $130 \mathrm{ra} 47$.

Sylvius N, Tesson F. 2006. Lamin A/C and cardiac diseases. Curr Opin Cardiol 21: 159-165.

Towbin JA, Bowles NE. 2002. The failing heart. Nature 415: 227-233.

Towbin JA, Hejtmancik JF, Brink P, Gelb B, Zhu XM, Chamberlain JS, Mccabe ERB, Swift M. 1993. X-linked dilated cardiomyopathy-molecular-genetic evidence of linkage to the Duchenne muscular-dystrophy (dystrophin) gene at the Xp21 locus. Circulation 87: 1854-1865.

Tse HF, Ho JCY, Choi SW, Lee YK, Butler AW, Ng KM, Siu CW, Simpson MA, Lai WH, Chan YC, et al. 2013. Patient-specific induced-pluripotent stem cells-derived cardiomyocytes recapitulate the pathogenic phenotypes of dilated cardiomyopathy due to a novel DES mutation identified by whole exome sequencing. Hum Mol Genet 22: 1395-1403.

Van Sligtenhorst I, Ding ZM, Shi ZZ, Read RW, Hansen G, Vogel P. 2012. Cardiomyopathy in a-kinase 3 (ALPK3)-deficient mice. Vet Pathol 49: 131-141.

Ware JS, Roberts AM, Cook SA. 2012. Next generation sequencing for clinical diagnostics and personalised medicine: implications for the next generation cardiologist. Heart 98: 276-281.

Wilkinson JD, Landy DC, Colan SD, Towbin JA, Sleeper LA, Orav EJ, Cox GF, Canter CE, Hsu DT, Webber SA, Lipshultz SE. 2010. The pediatric cardiomyopathy registry and heart failure: key results from the first 15 years. Heart Fail Clin 6: 401-413.

Yingchoncharoen T, Tang WW. 2014. Recent advances in hypertrophic cardiomyopathy. F1000Prime Rep 6: 12.

Zaragoza MV, Brandon MC, Diegoli M, Arbustini E, Wallace DC. 2011. Mitochondrial cardiomyopathies: how to identify candidate pathogenic mutations by mitochondrial DNA sequencing, MITOMASTER and phylogeny. Eur J Hum Genet 19: 200-207. 


\section{COLD SPRING HARBOR Molecular Case Studies}

\section{ALPK3 gene mutation in a patient with congenital cardiomyopathy and dysmorphic features}

Ahmet Okay Çaglayan, Rabia Gonul Sezer, Hande Kaymakçalan, et al.

Cold Spring Harb Mol Case Stud 2017, 3: a001859 originally published online June 19, 2017

Access the most recent version at doi: $10.1101 / \mathrm{mcs} . a 001859$
Supplementary http://molecularcasestudies.cshlp.org/content/suppl/2017/06/19/mcs.a001859.D Material C1

References This article cites 44 articles, 17 of which can be accessed free at: http://molecularcasestudies.cshlp.org/content/3/5/a001859.full.html\#ref-list-1

License This article is distributed under the terms of the Creative Commons Attribution License, which permits unrestricted reuse and redistribution provided that the original author and source are credited.

Email Alerting Receive free email alerts when new articles cite this article - sign up in the box at the Service top right corner of the article or click here. 